\title{
Universiteit
}

Leiden

The Netherlands

\section{The Ayatollahs and Democracy in Iraq}

Cole, J.R.I.

\section{Citation}

Cole, J. R. I. (2006). The Ayatollahs and Democracy in Iraq. Isim

Paper 7, 1-28. Retrieved from https://hdl.handle.net/1887/10072

Version: $\quad$ Not Applicable (or Unknown)

License: $\quad$ Leiden University Non-exclusive license

Downloaded from: $\quad$ https://hdl.handle.net/1887/10072

Note: To cite this publication please use the final published version (if applicable). 
The Ayatollahs and Democracy in IraQ 
The ISIM Papers represent individual lectures delivered at the ISIM. The aim of this series is both to allow the papers, initially presented before limited audiences, to be shared by the entire academic community and to contribute to the further development of the study of Islam in the modern world.

Published by:

International Institute for the Study of Islam in the Modern World (ISIM)

IS IM PAPERS:

1. James Piscatori

Islam, Islamists, and the Electoral Principle in the Middle East

2. Talal Asad

Thinking about Secularism and Law in Egypt

3. John Bowen

Shari'a, State, and Social Norms in France and Indonesia

4. Barbara D. Metcalf

'Traditionalist' Islamic Activism: Deoband, Tablighis, and Talibs

5. Abdulaziz Sachedina

The Role of Islam in the Public Square: Guidance or Governance?

6. Lila Abu-Lughod

Local Contexts of Islamism in Popular Media

7. Juan R.I. Cole

The Ayatollahs and Democracy in Iraq 


\section{THE AYATOLLAHS}

\section{AND DEMOCRACY}

\section{IN IRAQ}

Juan Rol.Cole

ISIM PAPER 7

AMSTERDAM UNIVERSITY PRESS IS I M L EIDEN 
Cover design and lay-out: De Kreeft, Amsterdam

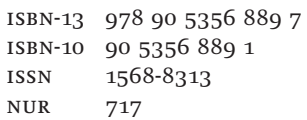

(c) Amsterdam University Press, Amsterdam 2006

All rights reserved. Without limiting the rights under copyright reserved above, no part of this book may be reproduced, stored in or introduced into a retrieval system, or transmitted, in any form or by any means (electronic, mechanical, photocopying, recording or otherwise) without the written permission of both the copyright owner and the author of the book. 


\section{The Ayatollahs and Democracy in IRAQ}

This ISIM Annual Lecture was delivered on 1 December 2005

at the Beurs van Berlage, Amsterdam.

Clerically-led Shiism in Iraq is undergoing a reformation, in which leading figures are attempting to reconcile the principles of Islam with those of the Enlightenment. This encounter between the two systems is hardly new, and the contradictions are hardly easy to work out. Yet the current attempt by ayatollahs to engage with the ideals of Jean-Jacques Rousseau is among the more thorough-going and institutionally promising in modern history. Here we will look at the clerical discourse on popular sovereignty and elections during the first eighteen months after the fall of Saddam.

What drove the Iraqi Shiite clerical leadership to champion elections and popular sovereignty in post-Baathist Iraq? Was this stance wholly new in that tradition, or were there precedents? Was the American administration helpful to them in developing this vision, or did it attempt to stand in its way? How did their stance articulate with popular politics in the country, during a time of both military and administrative occupation by the Americans? How did these thinkers reconcile the secular implications of popular sovereignty (after all the people are free to choose to be irreligious) with their own dedication to establishing an Islamic state in Iraq, ruled by Islamic law?

Notions of the basis of political and religious authority have changed considerably within the Twelver Shiite tradition. They hold that after the death of the Prophet Muhammad, legitimate authority should have passed to his son-in-law, Ali b. Abi Talib, and thence to a line of his descendants. With the exception of Ali himself, these "Imams" or divinely appointed leaders never actually came to power, though they exerted spiritual influence over their followers. That line of Imams ended with the Twelfth Imam, who is said to have vanished into a mystical realm in CE 873, from which he will someday return. The solution to the problem of legitimate authority in the absence of the Prophet Muhammad was now itself problematic, since there were no more Imams. Shiites dealt in various ways with the problem of who should 
rule that ensued from the Imam's disappearance or occultation, but for the most part they were willing to suffer with a "common-law" ('urfi) or civil state until his messianic advent. The illegitimacy of political life under these conditions was mitigated in the view of the majority school of jurisprudence by the ability of a new corps of seminary-trained clerics to authorize some state functions, such as the collection of religious taxes, the holding of Friday congregational prayers, the appointment of religious jurisconsults, and the declaration of defensive holy war. Monarchy and, in modern times, republics and nation-states were thus seen as unfortunate necessities, only partially legitimate, but the best one could do until the Imam returned. ${ }^{1}$ From the late 1960s, Khomeini put forward a novel theory that in the absence of the Imam, the trained Shiite clerics should rule, in accordance with Islamic law. He was dismissive of democracy, saying that if the people disagreed with the religious texts, the people would be wrong. ${ }^{2}$

Iraqi Shiite theorists of the Islamic state for the most part had a different vision than that of Khomeini, and their writing on this matter much preceded his. ${ }^{3}$ The Da'wah Party was formed in the late 1950 s in Iraq, envisaged as a Shiite response to the Communist and Baath Parties. ${ }^{4}$ Its main ideologue was Ayatollah Muhammad Baqir al-Sadr of Najaf, who envisaged

1 Many of these themes are treated in Juan Cole, Sacred Space and Holy War: The Politics, Culture, and History of Shi'ite Islam (London: I. B. Tauris, 2002).

2 Ervand Abrahamian, Khomeinism: Essays on the Islamic Republic (Berkeley: University of California Press, 1993).

3 For the historical background of modern Iraqi Shiism, see Pierre-Jean Luizard, La formation de l'Irak contemporain [The Formation of Contemporary Iraq] (Paris: Editions du Centre national de la recherche scientifique, 1991); Yitzhak Nakash, The Shi'is of Iraq (Princeton: Princeton University Press, 1994); Meir Litvak, Shi'ite Scholars of Nineteenth Century Iraq (Cambridge: Cambridge University Press, 1998); Faleh 'Abd al-Jabar, ed., Ayatollahs, Sufis and Ideologues (London: Saqi Books, 2002).

4 Salah al-Khursan, Hizb al-Da'wa al-Islamiyya: Haqa'iq wa watha'iq [The Islamic Da'wa Party: Facts and Documents] (Damascus: al-Mu'assassa al-'Arabiyya li'l-Dirasat wa'l-Buhuth alIstratijiyya, 1999); Ruhaimi, “The Da'wa Islamic Party,” in 'Abd al-Jabar, Ayatollahs, pp. 149161; Keiko Sakai, "Modernity and tradition in the Islamic movements in Iraq," Arab Studies Quarterly, Vol. 23, No. 1 (Winter 2001), pp. 37-52; Mahan Abedin, “Dossier: Hezb al-Daawa al-Islamiyya: Islamic Call Party,” Middle East Intelligence Bulletin, Vol. 5, No. 6 (June 2003) at: www.meib.org/articles/o3o6_iraqd.htm ; Hanna Batatu, "Shi'ite Organizations in Iraq: AlDa‘wah al-Islamiyah and al-Mujahidin,” in Juan R. I. Cole and Nikki R. Keddie, eds., Shi‘ism and Social Protest (New Haven: Yale University Press, 1986), pp. 179-200; Joyce N. Wiley, The Islamic Movement of Iraqi Shi'ites (Boulder, Co.: Lynne Rienner, 1992). 
an Islamic republic, but not one necessarily ruled by clerics. ${ }^{5}$ The republic was to implement Islamic canon law (sharia), and would have a consultative council (shura). These are stock elements in any Islamist political program of the twentieth century. It is seldom made clear by thinkers such as Muhammad Baqir al-Sadr (or by his contemporaries, such as Abu al-Ala' al-Mawdudi of the Jama'at-i Islami in Pakistan or Muhammad al-Hudaybi of the Muslim Brotherhood in Egypt) how the "consultative council" comes into being or to whom it is responsible, apart from God. That is, the invocation of the consultative element did not necessarily imply parliamentary democracy for al-Sadr. A Leninist style democratic centralism would have fit the "consultative council” language just as well. Still, a parliamentary system with open elections would not be incompatible with al-Sadr's vision in any obvious way, in contrast to the thinking of Khomeini, which was actively hostile to the notion of popular sovereignty.

Although he was a quietist earlier in his career, Grand Ayatollah Ali Husayni Sistani emerged in the twenty-first century as among the more important shapers of democracy in modern Iraq. He was born in 1930 in Mashhad, eastern Iran. Sistani, from a clerical family, carried out his initial studies with his father and other great clerics in the city of his birth. Around 1948 he went off for higher studies to Qom, not far from the capital of Tehran in the north-central part of the country. There he worked with the greatest Shiite authority of the time, Ayatollah Husayn Burujirdi. Late in 1951, the young Sistani went to Najaf in Iraq to complete his education, and ended up staying there the rest of his life. For the next decade, he studied with the leading jurists of that city. To any extent that Sistani thought about political matters, he appears to have been shaped by the ideals of the Constitutional Revolution in early twentieth century Iran (1905-1911). In post-Saddam Iraq, Sistani referred proudly to the role of Najaf clerics in theorizing a synthesis of Shiite Islam and Western-style constitutionalism in 1905-1911. That experiment ultimately failed, but left behind a body of thought on which clerics of Sistani's generation continued to draw.

In 1968 the secular, Arab nationalist Baath Party came to power in a coup. Sistani himself adhered to the quietism of Burujirdi (d. 1961), Grand Ayatol- 
lah Muhsin al-Hakim (d. 1970), and Grand Ayatollah Abu al-Qasim Khu'i (d. 1992). He therefore avoided coming into direct conflict with the one-party state, though he clearly rued the way in which the seminary city of Najaf was reduced to a shadow of its former self and the Shiite clergy were driven into exile or killed in the dozens. Sistani also regretted the excesses of the Islamic Republic from 1979 in his homeland, where Ayatollah Ruhullah Khomeini instituted a clerical theocracy. He told one visiting scholar, "Even if I must be wiped out, I will not let the experience of Iran be repeated in Iraq."

In 1979, Saddam Hussein made a coup within the Baath Party and took it in an increasingly draconian direction. Alarmed by the Islamic Revolution in neighboring Iran, Saddam cracked down hard on the Shiite political movements. He outlawed the Da'wah Party and made membership in it a capital crime. He had major leaders arrested and many of them executed. Others fled in droves to Tehran. There, in 1982, Khomeini urged them to organize an umbrella group, the Supreme Council for Islamic Revolution in Iraq (SCIRI). It initially included the Da'wah Party, but its leaders left in 1984 to maintain their independence. In 1984, Muhammad Baqir al-Hakim became its leader, and the organization increasingly consisted of his loyalists. ${ }^{7}$ The Supreme Council for Islamic Revolution in Iraq would emerge as among the more important political parties after the Americans overthrew the Baath.

After leaving SCIRI, lay Da'wah Party leaders in Tehran became increasingly uncomfortable in clerically-dominated Tehran, and many left for London, which quickly became the center of gravity of the party. There, they began to see the benefits of the Westminster model of "consultation." By 2002, Da'wah Party leaders in exile had increasingly moved to a full-fledged parliamentary model. It no doubt helped that affirmation of a commitment to parliamentary governance was central to any alliance with the United States in the buildup to the invasion, an alliance into which the London branch of the Da'wah allowed itself to be drawn. In December of 2002, as the war was building, a Damascus-based leader of the Da'wah Party, Nuri Abu al-Mahasin, then going by his nom de guerre of Jawad al-Maliki, was asked by the Beirut daily al-Safir what sort of government he envisaged in post-war Iraq. He replied, "We prefer the democratic game. What the people decide is the thing that matters,

6 Interview with Ghassan Attiyah, Ottawa, May 14, 2006.

7 Mukhtar al-Asadi, Al-Taqsir al-Kabir bayna al-Salah wa al-Islah [Mere Passive Goodness Falls Far Short of Active Reform] (Beirut: Dar al-Furat, 2001). 
away from sects and ethnicity. This is although we call for an Islamic - not religious - state as long as the Iraqis voluntarily and willingly support such a state." His distinction between an "Islamic" and a "religious" state is probably actually between a lay-governed regime that foregrounds Islamic canon law and a clerically-ruled theocracy. The lay leaders of the Da'wah Party had never liked the Khomeinist model of rule by a supreme jurisprudent. What is remarkable here, however, is al-Maliki's full endorsement of a universalist version of popular sovereignty.

The Iraqi clerics in the post-Saddam period showed increasing openness to the idea of popular sovereignty as expressed at the ballot box. On May 10, the leader of the Supreme Council for Islamic Revolution in Iraq, Ayatollah Muhammad Baqir al-Hakim, returned to his native country from exile in Iran. He arrived at a time when a new American civil administrator, Paul Bremer, had taken the reins of power. His predecessor, Jay Garner, had taken steps toward appointing a governing council made up of Iraqi expatriate politicians plus the Kurdish leaders, and from all accounts he hoped to move quickly toward holding a congress in summer of 2003 that would elect an Iraqi government, so that the Americans could swiftly depart. When Bremer arrived, however, he set aside Garner's plans and intimated that he would rule Iraq single-handedly for some time, perhaps for years.

Bremer intended to follow a seven-stage plan for putting Iraq back on its feet. One stage was to appoint a committee of Iraqis to work with American advisers in drafting a new permanent constitution for Iraq. Bremer announced his intentions in early June. Muhammad Baqir al-Hakim made this plan the center piece of the first Friday prayers sermon he preached in Najaf, on June 6. He observed, "The United States suggests that the coalition forces form a council, which it itself appoints. This council is to sit down, draft a constitution and present it to the people." He then thundered, "This is a path that we and the authorities believe is an incorrect path." 9 Al-Hakim went on to say that if the new Iraqi government was to function well, it would have to be established on several key pillars. They included respect for the will of the people as expressed at the ballot box, respect for ethnic minorities via a federal system of government, and respect for Islam through the 17 December 2002, FBIS.

9 "SCIRI Spokesman Rejects US Proposal to Appoint Iraqi Council," Jazeera TV, Doha, in AArabic 1716 GMT 6 Jun 03. BBC Monitoring, June 7, 2003. 
enforcement of Islamic canon law (sharia). The notion of an American viceroy high-handedly appointing a committee to write the constitution offended the first of these principles, i.e. popular sovereignty as expressed through elections and referenda. An American-sponsored constitution, moreover, would almost certainly lack a strong element of Islamic law. Al-Hakim did not see sharia and popular sovereignty as contradictory, but rather as overlapping. He had a point. In a society that is 96 percent Muslim, Islamic canon law and Muslim customary law clearly would be extensively incorporated into law and administration in any truly democratic system. He feared, however, that Bremer's way of working would be neither democratic nor Islamic.

In an interview with Der Spiegel that appeared the day after the sermon, al-Hakim reiterated his commitments. He told the interviewer, "We want no dictator, no one-man or one-party state. Iraq will be a democratic state, in which the rights of all the groups in society will be respected. It will be a state in which the values of Islam and all the other religions will be respected and served." ${ }^{10}$ He went on to say that if Iraqis were given their head, they would be able to establish a government of their own within four weeks. It is likely that, ironically enough, it was not only the excesses of Khomeinism in Iran but also the figure of American viceroy in Iraq, J. Paul Bremer III, that helped push clerics such as al-Hakim toward democratic thinking. Iraq was in June of 2003 under one-man rule, that of Bremer. Democracy, and appeals to the ballot box and popular sovereignty, were emerging as tools whereby the Shiite clerics could undermine the legitimacy of Bremer's rule and claim the mantle of the people's choice for themselves.

Al-Hakim was not alone in his commitment to both the ballot box and to sharia. Grand Ayatollah Sistani of Najaf, who had even more authority, adopted the same position. In his first major fatwa after the fall of Saddam, critiquing the American plan to appoint a committee to draft the Iraqi constitution, Sistani rejected the Khomeinist tradition by also accepting the principle of popular sovereignty. In his ruling or fatwa of 28 June, 2003, Sistani explained that there was no way of being sure that the American-appointed committee "will draft a constitution that conforms with the highest interests of the Iraqi people and would express its national identity, one basis of which is the pure Islamic religion and noble social values." Sistani insisted that any body that drafted the new constitution would have to be elected by 
the people. He said that the draft constitution should then be submitted to a national referendum.

In other statements coming out of Najaf, it was clear that the high clerics, including Sistani, saw governmental legitimacy as deriving from two sources. One was the seal of approval (al-imda') given by the grand ayatollahs in Najaf. The other is the approval or agreement of the people through a general election. ${ }^{11}$ In the absence of these two, the American-appointed Interim Governing Council lacked legitimacy, according to the communiqué. This statement recognizes two sources of legitimacy for an Iraqi government. The dual sources of legitimacy did not imply, in the thinking of Sistani and those around him, any sort of theocracy.

On November 15, US civil administrator Paul Bremer made a pact with the Interim Governing Council that he himself had appointed, which called for council-based elections in May, 2004. ${ }^{.2}$ The plan had five basic stages. First, the Interim Governing Council would craft a Basic Law allowing a transitional government to be elected and operate. Second, by the spring, each of Iraq's 18 provinces would hold conventions made up of notables, elders and tribal chieftains. These conventions would elect altogether over two hundred members to an interim parliament, based on proportional representation. This interim parliament would in turn elect a prime minister. This process would be complete by June, 2004. Third, at that point, Mr. Bremer's Coalition Provisional Authority would hand over power to the new government and close up shop. The US and UK military would remain in Iraq, however, and the new government could invite other international contributors of troops and other help. Fourth, the interim government would hold elections for delegates to a constitutional convention to draft the new constitution, in accordance with the fatwa or legal ruling of Grand Ayatollah Ali Sistani. Fifth, formal elections on the basis of one person, one vote, would be held to install a new government, to which the interim government will hand power. This plan clearly was intended to achieve a restoration of sovereignty to the Iraqi people without risking their voting in an anti-American government. The Americans appear to have believed that if genuine elections were permitted in spring of 2004 there was a risk that extreme Arab nationalists

"Hawzat al-Najaf Tasdur Fatwa didd Qanun al-Jinsiyyah al-Iraqiyyah," ash-Sharq al-Awsat, October 7, 2003. 
and radical Sunni and Shiite Muslims might have undue influence in the parliament. The system Bremer put forward involved voting by members of the provincial and municipal governing councils established by the Americans and British. These council members had gotten into power because of small, unrepresentative selection processes overseen by the occupation authorities and companies it hired.

Signs of discontent with the November 15 agreement soon began surfacing, even among members of the Interim Governing Council that had approved it. Muhammad Baqir al-Hakim, the head of the Supreme Council for Islamic Revolution in Iraq, had been assassinated on August 29, 2003, and was succeeded by his brother, Abdu'l-'Aziz. The new SCIRI leader complained on November 18 about the US plan for handing over sovereignty to an Iraqi government by June. He said the process whereby this plan was worked out was rushed, and was largely dictated to the Iraqis. The Associated Press quoted him as saying, "The Americans were insisting that they wanted to end this matter quickly. There was rushing and although there were reservations by other council members ... regrettably [the Americans] did not stop or give more time for unanimous consent to be reached. The Iraqi people were pushed aside and the Iraqi people should play an important role. This contradicts the principles of democracy." ${ }^{13}$ The "caucus-based" elections pushed by the Bush administration were more oligarchical than democratic, and the Shiite clerics opposed to the scheme focused on this flaw in their critique, positioning themselves as champions of genuine popular democracy.

One subtext of the Shiite clerics' disagreement with the Bremer plan, however, was the struggle between a secular and a religious vision of Iraq's future government. A "democratic" process, in the eyes of the clerics and their supporters, was also one that would ensure the enshrining of indigenous values, i.e. Islam. The Bremer plan made no mention of the place of Islam or Islamic law in the new government, and the provincial and municipal governing councils had been stacked by the Americans and British with relatively secular, pro-Western notables. This dimension of the dispute was made clear by Adil 'Abd al-Mahdi of the Supreme Council for Islamic Revolution in Iraq, who told a Western wire service the next day, "This agreement lacks any reference to the respect of the Islamic identity of most of the Iraqi 
population and the guarantee of the rights of other religions and sects." ${ }^{14}$

Shiite leaders had other critiques of the Bremer plan. Among them was that the electorate he envisaged, members of the municipal and provincial councils, was a hodgepodge. IGC member Ahmad Shiya' al-Barak, a human rights lawyer and a leader of the Al Bu Sultan tribe of Babil province, told al-Hayat that before elections could be held, the municipal and provincial councils had to be reformed..$^{15}$ He pointed out that some municipal councils doubled as provincial ones (i.e. they have authority over the capital as well as the whole province). They differed in how they were chosen, differed with regard to how many members they had, and no standard set of regulations specified their functions. Al-Barak was clearly concerned that if the councils - many of them formed under watchful US eyes - were to function as the election commissions, they could have been crucial in shaping the electorate and the outcome of the polls. Therefore, their nature was the key to the elections as the Bremer Accord envisaged them. He wanted "vast reforms" in these councils before those elections.

Although Abd al-Mahdi, ironically enough, had earlier been the one who assured Bremer that Grand Ayatollah Sistani accepted the outline of the plan, either he was prevaricating or it was not fully explained to the sage of Najaf. When the grand ayatollah understood that the Iraqi parliament was to be elected by what Americans called "caucuses," rather than on the basis of one person, one vote, Sistani rejected this plan out of hand. In response to the questions of Anthony Shadid of the Washington Post, he gave his most explicit fatwa yet on popular sovereignty. Responding to Bremer's council-based plan, he said, "The instrumentality envisaged in it for electing the members of the transitional legislature does not guarantee the formation of a parliament that truly represents the Iraqi people. It must be changed to some other method, which would guarantee it. And that is [direct] elections, such that the parliament would derive from the will of the Iraqis and would represent them in a just manner and will safeguard it from any challenge to its legitimacy." ${ }^{16}$ Sis-

14 “Iraqi Shiites unhappy with 'unclear' agreement on handover of power," Deutsche PresseAgentur, November 20, 2003.

15 Al-Hayat, November 24, 2003, summarized at www.juancole.com for November 24, 2003.

16 "Fatwa for Anthony Shadid," online in Arabic at www.sistani.org/messages/antoni.htm; reported in the Washington Post by Anthony Shadid and Rajiv Chandrasekaran, "Cleric Renews Call for Iraq Elections,” November 29, 2003, but with a less technical translation of the Arabic than the one I give above. 
tani also told visitors in this period that he was concerned that the November 15 agreement made no explicit place for Islam and gave no guarantees that un-Islamic laws would be prohibited.

Sistani's position insisting on open elections met with immediate acclaim from the Shiite religious leaders and parties. Even the radical young cleric Muqtada al-Sadr weighed in on the side of one-person, one-vote polls. His spokesman came out to say, "All bodies that are not elected will be deemed illegitimate." ${ }^{17}$ Bremer orchestrated a vote on the Interim Governing Council against Sistani's plan for direct elections, but defying the grand ayatollah would not prove politic in the end. Ironically, Shiite religious forces that earlier had had little interest in democracy now rallied around the idea of Iraqi popular sovereignty and direct elections, including the Sadr movement. Paul Martin of the Washington Times reported that on December 3 :

Members of a Shi'ite Muslim movement demonstrated outside the local coalition headquarters yesterday to demand that elections be held before a new government and constitution are established. The protesters held up banners and daubed cement blocks around the headquarters building with slogans such as "Down U.S.A." and "Death to America." "At present, we are in the stage of peaceful negotiations," said a white-turbaned sheik from the al-Sadr faction, the most hard-line of the three main Shi'ite political movements. "I pray to Allah that we do not have to move to violence and killing," he said as he strode with 250 followers toward the heavily protected headquarters on the banks of the Euphrates River. ${ }^{18}$

The Hilla demonstrations in favor of free and open elections had a local context, insofar as many Shiites opposed the American-appointed governor of the province, Jawad Witwit, whom they accused of being an ex-Baathist, and they conducted demonstrations against this appointed figure in December that forced him to resign. Then the US appointed a former air force officer as governor, but the activist Shiites considered him unacceptable as well and mounted more demonstrations. Rajiv Chandrasekaran of the Washington Post

17 Nadra Saouli, “Iraq's Shiite Muslim majority seeks to exert its political weight," AFP, November 27, 2003; for the Sadr Movement see Juan Cole, "The United States and Shi'ite Religious Factions in Post-Ba "thist Iraq," The Middle East Journal, Volume 57, Number 4, Autumn 2003, pp. 543-566.

18 Paul Martin, "Shi'ite demonstrators demand elections," The Washington Times, December 4, 2003. 
reported on one such rally: "'Yes, yes for elections!' shouted the protesters, a collection of students, clerics and middle-aged professionals whose ranks swelled to more than 1,00o. 'No, no to appointment!'." ${ }^{9}$ They said that they had taken heart from Sistani's call for direct elections. They also no doubt feared that Bremer's "caucus-based" elections would produce similar high officials for the whole country. The Hilla demonstrations of fall 2003 showed that the rhetoric of open elections was being taken up by the Iraqi street. The techniques of crowd politics pioneered by the Sadr movement in postSaddam Iraq were to be adopted by other Shiite religious groups with great effectiveness.

Other clerics who worked under Sistani's penumbra, whether in religion or politics or both, took up the discourse of the popular will. Abd al-'Aziz alHakim became president of the Interim Governing Council, and in December he visited Germany for consultations with Chancellor Gerhard Schroeder. The Lebanese Broadcasting Company satellite television news anchor reported that al-Hakim "has renewed his support for a bigger UN role in bringing democracy back to Iraq. Following his meeting with German Chancellor Gerhard Schroeder in Berlin, Al-Hakim said that he aims to establish a democratic and free state in Iraq that respects all religions and human rights." ${ }^{20}$ While in exile in Tehran in the 1980s and 1990s, the al-Hakims had gone over to Khomeinism, but clearly on their return to Iraq they had begun rejecting dictatorial clerical rule as a model and begun acknowledging at least some elements of popular sovereignty, though what they meant by "democracy" and "human rights" might not have mapped exactly onto contemporary Western ideals. Still, for Abdu'l-'Aziz al-Hakim to use this discourse is itself significant.

When Bremer and his Interim Governing Council rejected Sistani's demands, the grand ayatollah orchestrated a campaign to rescind the November 15 agreement. Democracy and popular sovereignty were emerging as central tools for the assertion of an indigenous, Iraqi, Shiite national identity, enshrined in a constitution that flowed from the sovereign people. Bremer

Rajiv Chandrasekaran, "A troubling wound opens for the U.S. in Hilla," Washington Post, December 13, 2003.

20 “LBC: IGC's Al-Hakim Meets Schroeder, Renews Support for 'Bigger UN Role' in Iraq," Beirut, LBC Satellite Television in Arabic 150o GMT, 18 December, 2003. FBIS. See also Program Summary: Al-Manar Television, in Arabic 1830 GMT, Thursday, December 18, 2003 , FBIS. 
and his caucuses and his high-handed interim constitution were the antithesis of the autochthonous, the popular and the authentic.

Sistani then demonstrated the sort of hold he had on the Iraqi street. In mid-January, 2004, he called tens of thousands of demonstrators into the streets of Basra and Baghdad, demanding direct elections. He also said that the United Nations should send an envoy to investigate the political situation in Iraq and to look into the feasibility of holding direct elections in May, 2004 .

On January 14, Sistani held a meeting in Najaf at which he encouraged visiting clan leaders of Rumaitha, Samawah, and other middle Euphrates areas to insist on general elections as a means of achieving a new, sovereign Iraqi government. He promised the sheikhs of that region that they would exercise power, not "those who came from abroad." He was referring to the members of the Interim Governing Council, many of whom returned from long years of exile in the West or in Iran after the fall of Saddam. Raghida Dergham quoted him in as saying, "Authority must be yours, and the coming parliament must be composed of elected children of the people."21

The tribal leaders from these areas had allied with the Shiite clergy in the spring, 1920, Great Rebellion against the British Mandate, which the British put down with difficulty and which led to the British colonial experiment in Iraq being much briefer than hawks such as Churchill had envisaged (it ended in 1932). Sistani invoked this history at the Najaf colloquy. He said, "We want you to be revolutionaries, just as we want you to exercise sovereignty." He added, "You must play a great role, just as you played a role in the 1920 Revolt." In rural areas of Iraq, the sheikhs still have substantial authority, though most Iraqis are now urban.

The invocation of 1920 was not, however, intended to signal that Sistani wanted a violent struggle. Sistani's representative, Shaikh Muhammad Taha al-Husayni, told a crowd of students at Kufa on the same day as the Najaf meeting, "We must be conscious of our rights and demand them, as is appropriate to a prepared people, since no one has the right to impose even one article of the Iraqi constitution." 22 He went on to urge non-violent action, saying that armed resistance would not serve the Iraqis at that point. Just as 
Bremer's one-man rule had helped push Iraqi clerics toward a discourse of popular, national sovereignty, so too had the prospect that a foreign, imperial power, might impose an alien constitution.

On Thursday, January 15, 2004, Sistani's representative in Basra, Hujjat al-Islam 'Ali 'Abd al-Karim Safi al-Musawi, led a huge demonstration of some 40,000 in a procession through public streets. The crowds carried placards with slogans on them such as "Yes, Yes to Sistani, No, No to an Appointed [Government]," and "We Want a Constitution Written by Elected Iraqis." When the crowd arrived at the mosque toward which they had marched, Safi al-Musawi addressed them, criticizing the November 15 agreement that forestalled open elections. He said that it had "been prepared with a haste that was not just, and that it did not "reflect the pluralism of Iraqi society" and would cause trouble among Iraq's ethnic groups. He defended the idea of holding general elections, considering that it was possible to call Iraqis holding food ration cards to participate in the polling. Pamphlets circulated through Basra with slogans written on them, such as "Peaceful demonstrations are the best way of showing your support for the new democratic order, and the multinational forces are here to support your mobilization." (The pamphleteers appear to have wanted to assure crowds that it would be safe to come out.) The demonstrations were supported by the Da'wah Party and the Supreme Council for Islamic Revolution in Iraq, though secular parties were absent. ${ }^{23}$ That Friday, Shaikh Abd al-Mahdi al-Karbala'i, Sistani's representative in the shrine city, warned that the coming days would witness demonstrations, strikes and even possibly confrontations with American forces if the Coalition insisted that it was impossible to conduct elections before the transfer of sovereignty to Iraqis.

On January 19, the following Monday, the Shiite religious forces organized a demonstration estimated at 100,000 strong in the capital. According to the Gulf daily al-Watan, they were expressing their support for Sistani's demands that elections be held before sovereignty was transferred to Iraq by the US. ${ }^{24}$ The demonstration clearly was dominated by religious forces and was led by young Shiite clergymen who said that they represented various seminaries in Baghdad. The procession began at $8 \mathrm{am}$. They crossed the

23 "Tazahurah da'man li al-Sistani fi al-Basrah," Middle East Online, 16 January 2004, at www. middle-east-online.com/iraq/?id=20692.

24 "Muzahirat fi Baghdad," Al-Watan, January 20, 2004, at www.alwatan.com/graphics/2004/ 01Jan/20.1/dailyhtm1/news1.html. 
Muhammad al-Qasim bridge and headed for the Mustansiriyyah cathedral mosque in the center of Baghdad. The young clerical leaders carried posters and placards, most prominently of Sistani, while others functioned as parade marshals, urging the crowd to remain calm and to refrain from chanting insults against the Interim Governing Council. When asked, the young clerics said that no one movement had called the demonstrations, but that rather they represented the whole Iraqi people, and that the crowd had gathered to express its support of the grand ayatollah. Shaikh Muhammad al-Kawarani said, "There is no party that organized the demonstration. The people organized themselves, since they want their right to an election." Another young cleric, Muhammad Sa'id, who was urging the crowd to stick to the route and not to spill onto side streets, said, "We are all Muslims and all of us are participating. What we want is free elections, nothing else." Observers could distinguish thick concentrations in the crowd of supporters of the Supreme Council for Islamic Revolution in Iraq and of Muqtada al-Sadr. The crowd mingled slogans demanding elections and stressing the right of the Iraqi people to choose their leaders with religious chants, such as "Yes, yes, to Islam!" and "There is no deity but God and Muhammad is his Prophet!" They held aloft placards in Arabic and English urging elections, with phrases such as "Yes, yes to the religious leadership, and yes, yes to elections" and "The Surest Guarantee of True and Just Representation is Elections" and "Citizens, the Future will be Decided in the Coming Months! Be Zealous in Excercising your Rights in Determining the Course of Events!" The 5,000 out by the bridge called on the United Nations to exert pressure for elections, and carried placards with slogans such as, "We Ask the United Nations to Intervene in the Method of the Elections." A representative of the Supreme Council for Islamic Revolution in Iraq, Sabah al-Musawi, told Agence France Presse, "We support the position of Sistani, since democracy accords with his views. We desire wide participation through free elections, not imposed appointment." He added, "We cannot in the future defend Iraqi representatives elected by small groups." One of Sistani's representatives, who helped organize the demonstrations, said, "We Iraqis are a civilized people and are capable of deciding our fate." He said that no appointed government could be depended on to give Iraqis their rights. He stressed, "The government would have no legitimacy, and the Iraqi people would neither cooperate nor interact with it, save if it is the Iraqi people who elect it." The Bush administration immediately backed off, faced with these massive rallies, and cooperated with the sending of a UN 
envoy, Lakhdar Brahimi, to determine when and how (rather than whether) open elections would be held. ${ }^{25}$

Meanwhile, members of the Interim Governing Council who earlier had favored the US approach to carefully controlled elections, based on the Coalition-appointed provincial councils, defected to Sistani. Ahmad Chalabi told a skeptical audience at the arch-conservative American Enterprise Institute in Washington, DC, that he now favored open elections and believed they could be held. And 'Abd al-'Aziz al-Hakim, leader of the Supreme Council for Islamic Revolution in Iraq with its 15,000-strong Badr Corps paramilitary, told Reuters the same thing in late January: "It can be done, if we want it and make the effort. I believe they can be run." Az-Zaman reported that al-Hakim admitted, "Ideally elections would depend on the existence of a census, an electoral law, and a law governing parties ... There are problems ... But I believe that [elections] will express the opinion and the will of the people ... will give a voice to all, and holding them is feasible." 26

In a February 2004 interview with the German magazine, Der Spiegel, Sistani said that he felt that the only way forward out of the quagmire was democratic elections. ${ }^{27}$ When the German interviewer inquired as to whether they might not produce a tyranny of the Shiite majority, Sistani demurred. "Not at all. Even if a certain community holds a majority in numbers, this will not lead to the creation of a political majority, because in every community there are different political orientations." He felt it was important that governments succeed one another peacefully, something that had been rare during his lifetime in Iraq. He added, "Also, since the majority of the Iraqi people are Muslims, they are sure to choose a system which will respect the principles of the Islamic Sharia, and also protect the religious minorities." Sistani's generousness of spirit blinded him to the need for constitutional and institutional protections for minorities, and to the ways in which implementation of Islamic law would disadvantage Chaldean and Assyrian Christians, heterodox Yazidis, and secularists, including secular women. His analysis of the fractured character of Shiite politics and the ability of minori-

25 Diamond, Squandered Victory, pp. 135-139.

26 Al-Zaman, January 26, 2004, via Informed Comment, January 26, 2004 at www.juancole. com/2004/01/question-of-elections-in-iraq-in-past.html.

27 The interview is in Arabic at Sistani.org; the translations here are from "Newspaper Interview with Grand Ayatollah Ali al-Sistani . . translated from a German Interview by Der Spiegel, Posted Feb 22, 2004," Federal News Service, February 24, 2004, Lexis-Nexis. 
ties such as the Kurds and Sunni Arabs to make their voices heard would be shown to be inaccurate in 2005, when the religious Shiite bloc, the United Iraqi Alliance, gained a majority in parliament. The subsequent elections of December, 2005, however, would produce a deeply divided parliament more closely resembling the one Sistani envisaged for Der Spiegel.

A United Nations envoy prepared to come to Iraq to make a determination as to whether open elections were possible as early as that May, as Sistani believed. On February 4, Shaikh Abd al-Mahdi al-Karbala'i, Sistani's representative in the holy city, "said that if the UN team ruled elections were not feasible before the 30 June handover deadline, the Shia clergy would 'insist on a formula closer to elections than designations." 28

The issue continued to resonate at the local level, just as it had at Hilla. The next big struggle was in Nasiriyah. On January 28, a very large crowd, estimated by the Iraqi press as in the thousands, demonstrated against the Coalition-appointed governor of Dhi Qar province, Sabri Hamid Badr al-Rumayd. On Wednesday, February 4, another big rally was held, according to the Baghdad daily al-Zaman. The Virtue Party of Ayatollah Muhammad Ya'qubi, led in Nasiriyah by Shaikh As'ad al-Nasiri, and the Sadr movement of Muqtada al-Sadr, led locally by Shaikh Aws al-Khafaji, had repeatedly demanded that the local provincial council be dissolved, since it had been appointed by the Coalition Provisional Authority, and they viewed the governor elected by this appointed body as illegitimate. Under popular pressure, several of the members of the provincial council resigned.

The Iraqi police in Nasiriyah declined to intervene against the demonstration, and stood aside as spectators. The representative of Paul Bremer in the city, John Bourne, went on local television to explain that direct elections could not be held to select a new provincial council. He called on everyone to remain calm. Despite having announced the resignation of some members of the current provincial council "for private reasons," he declined to question its legitimacy, and merely promised to add other members to replace the ones who had resigned. With the prospect of national elections sometime later that year, popular dissatisfaction with the US- and British-appointed provincial councils was used by the Sadrists and the Virtue Party in an attempt to force direct elections at the provincial level before national elections were held. The distinction between "appointment" by a foreign power and popular 
sovereignty as expressed at the ballot box was key to these local demonstrations in 2004. ${ }^{29}$

The issue remained hot at the national level as well. On February 8, a political adviser to the Supreme Council for Islamic Revolution in Iraq, Sayyid Muhsin al-Hakim (a brother of Abd al-'Aziz) gave an interview on issues in democracy and elections in the Persian newspaper Iran..$^{30}$ He began by defining what the Iraqi Shiites wanted. "Democracy can be regarded as one of the important parameters that create security and stability in a country. Democracy means that each person in society enjoys the rights of a citizen, can play a decisive role in determining his social and political fate, and can elect a government of his own choice. This is the accepted definition of democracy in political philosophy." He condemned the apparent tendency among "all the three higher levels" of Iraqi politics at that point (presumably Bremer, the Interim Governing Council and the United Nations) to engage in "suspicious moves that want to bypass the vote of the Iraqi nation on various pretexts."

Sayyid Muhsin conceives of the intervention of Sistani as an operation of civil society, the public sphere that is neither governmental nor private. Western theorists of civil society, from Hegel to Habermas, had not emphasized the role of religious institutions, in part because in European countries such as Germany the Protestant-Catholic divide was so significant as to make religion an unlikely platform for truly public, neutral interchanges, and so religion was increasingly conceived as part of the private sphere. The role of the Catholic Church in overthrowing Polish communism and the global religious resurgence of the late twentieth and early twenty-first centuries, however, have led many social theorists to look at religion as part of civil society. Sayyid Muhsin positions the Najaf religious establishment in this light, and defends its neutrality. He notes, "Analyses sometimes carried out by some sources show that the true motive in this has not yet been clarified." This is a way of saying that these observers suspected that Sistani was acting out of private or sectional motives, not out of truly public and national ones. He denies this charge, however: "Actually, one can say that the only objective that the religious reference point pursues is the institutionalization of democracy in Iraq and stabilizing the rights of the citizens based on the

29 Al-Zaman, February 7, 2004, via www.juancole.com/2004/02/sadrists-occupy-provincial-hqin.html.

30 "Iran: SAIRI Official Says Badr Organization Can Provide Security for Elections," Iran in Persian og Feb 04, FBIS, February 9, 2004. 
formula of one person, one vote." Sayyid Muhsin uses the universal reference-points of "the citizens," of the individual voter, of stabilized rights and democratic institutions, to characterize Sistani's program, eliding its sectarian and sectional context.

He adds, "A look at Iraq of the past shows that destabilization efforts were carried out on three major levels: dictatorship on all levels, the religious suppression of Shiites; and racial apartheid against the Kurds, the Turkmen, and the Assyrians." Here, he posits a parallel between the "religious suppression" of his own community and the "racial" repression against the ethno-linguistic groups. Both kinds of Iraqi ethnicity suffered under the Saddamist dictatorship. He continues, "Thus, the only alternative is elections and democracy, which takes into mind the Islamic identity of the Iraqi nation and includes all the elements that form the Iraqi nation's social fabric." The uneasy coexistence here of particularistic Shiite demands (majority rule and Islamic law) with national claims to rights for all citizens is mediated by "elections and democracy." This mechanism is envisaged as ending the threat of dictatorship, ending religious discrimination, and ending racial or linguisticallybased discrimination, all at once. He challenges the idea that the Shiites want elections only because they are the majority and will inevitably come to power that way. He insists that "the Iraqi Shiites and their sagacious religious point of reference [highest spiritual authority] have always wanted the vindication of the rights of the other nationalities in Iraq and the recognition of their basic rights and freedoms." In acting for their rights, the Shiite clerics insisted, they are securing the legitimate rights of all Iraqis. He goes on to threaten that if the Shiite community is thwarted in its demand for open elections, it would turn obstructionist and boycott the political process.

Other SCIRI leaders, such as Abd al-Aziz al-Hakim, wove the new discourse of national liberty through parliamentary elections into particularistic traditions of Shiite piety. In early March of 2004, he gave a sermon on the ninth of Ashura, commemorating the martyrdom of Husayn, the grandson of the Prophet Muhammad, the central ritual commemoration of Shiite Islam. It was carried in the newspaper al-Adalah (Justice) on March 4. In the Shiite narrative, Husayn had stood with the masses in what is now Iraq against the oppression of the Umayyad Empire, then was cut down at Karbala by the armies sent out by the Caliph Yazid on October 10, 680. Al-Hakim addressed the crowd, saying, "We ... pledge to our Imam al-Husayn to walk along his path, which calls for adherence to right, justice, and freedom, and rejects injustice, arbitrariness, and tyranny." In this litany, "freedom" is perhaps the 
only truly modern element, added by al-Hakim to the more traditional values of justice and right. Al-Hakim tied the passion of Husayn to the Iraqi Shiites' yearning for an end to occupation and the advent of an elected, democratic government:

The land of Iraq is the land of the holy places and the cradle of freedom, and our Imam Al-Husayn may peace be on him, is the leader of the martyred and father of the free peoples. In order to close the road to all kinds of dictatorships and to prevent a repetition of the bitter experience of Saddam's tyranny, our demand for this dangerous and sensitive stage of our struggling people's life is to insist on the holding of free and fair elections to enable our peoples to have their say and express their opinion about whom they may choose to represent them. ${ }^{31}$

He here suggests a cycle of descent into tyranny and ascent into liberation. The identification of Saddam Hussein with Yazid, the Umayyad persecutor of Imam Husayn, was by then a hackneyed trope in Iraqi Shiism. But in the context of March, 2004, al-Hakim's reference to preventing further dictatorship is an oblique reference to Bremer's one-man rule of Iraq. In folk Shiism, it had been said that whoever weeps a tear for the slain Husayn was guaranteed entry to paradise. That is, he is a salvific figure. Likewise, here, al-Hakim ties the symbology of the martyr's sacrifice for spiritual salvation to a rhetoric of the people's sacrifice for national liberation. Al-Hakim thus sets up a neat parallel between the martyrdom of Husayn in the seventh century and the rise of democracy in the early twenty-first century. Iraq was the scene of both epiphanies. In both cases a long period of tyranny led the people to rise up. Inspired by the sacrifice of the Prophet's scion, the Iraqi people now had the opportunity to institutionalize the values inherent in Ashura' of refusal to countenance oppression. Not only free and fair elections but also the rule of law are key to this new, continuous liberty. "The conferring peoples confirm the need to issue a permanent constitution in the country. The constitution should ensure the free and effective participation of all sectors of society in the administration of their country in legitimate and decentralized ways." In this passage, we hear an early echo of al-Hakim's largest disagreement with Sistani, over whether Iraqi governance was best 
pursued through a strong central government or through a decentralized, loose federalism.

In the end, the plan Lakhdar Brahimi worked out with his American and Iraqi interlocutors gave Sistani most of what he wanted, though he did not get his May elections. Open elections were planned for late January 2005, after an initial transition from a purely American administration of the country to an American-backed interim government. Sistani also got a United Nations resolution midwifing the new Iraq, internationalizing the process far beyond what the Bush administration had wanted.

In the build-up to elections in January 2005, other high Shiite religious authorities also weighed in on democracy and popular sovereignty. The Baghdad newspaper al-Furat reported on October 10, 2004, that Grand Ayatollah Muhammad Ishaq Fayyad, a colleague in Najaf of Sistani who originally hailed from Afghanistan, also supported the electoral process. He demanded that the elections be held on schedule (i.e. no later than January 30, 2005) and "added that the elections represent the first step in the right direction toward building a free Iraq and achieving justice and stability for the Iraqis." He elaborated on the security issue, saying "that the security situation is connected to the holding of the elections, which would lead to a free and democratic government." Implicit in the ayatollahs' statements was a conviction that only an elected government would have the authority and legitimacy to begin working on ending the foreign occupation of the country. Another Najaf grand ayatollah, Muhammad Sa'id al-Hakim, was asked if the religious establishment had a plan for the elections. He replied, "Its plan is to hold real and national elections that lead to the composition of a truly sovereign and independent government." He stressed that the objective of the religious establishment is to unify the national ranks and underscore efficiency and national will. The Rousseauan language of the national or general will recurs here, and it shows that Sistani was not alone in his interest in Enlightenment ideals about popular sovereignty. Sistani cobbled the Da'wah Party, the Supreme Council for Islamic Revolution in Iraq, and other Shiite religious parties into a single list, the United Iraqi Alliance. He advised Shiites to vote for it, and on January 30, 2005, it won a simple majority in the new parliament.

In conclusion, one can trace from April 2003 through January of 2005 a remarkable development in Shiite religious and legal thinking about democracy in Iraq. The ideals of elections, representation of the people, the expression of the national will, and a rule of law are invoked over and over again 
by the most prominent religious leaders. Unlike Khomeini in 1979, they are completely unafraid of the phrase term "democracy," and generally see no contradiction between it and Islam. These democratic convictions, of course, have an immediate context. They give the religious establishment a means to ensure that the Shiite majority in Iraq gains its political voice after decades of severe repression. They also pave the way to an independent, sovereign Iraq that may finally escape foreign domination. This instrumental utility of democracy, however, cannot entirely explain the ayatollahs' infatuation with it. Rather, they survived the dictatorships of Saddam and Khomeini alike, becoming disillusioned both with secularism and with authoritarian theocracy.

The Shiite clerics were both helped and hindered by the Americans. The Bush administration, having proved unable to discover the weapons of mass destruction on which it had premised the war, increasingly turned to democratization as the justification for the continued occupation of Iraq. This rhetoric of democracy could thus be appropriated and used against the US by Iraqi actors. The "one-man rule" of Paul Bremer became an easy target of criticism when the Shiite clerics expressed their new commitment to popular rule. The Americans also provoked a backlash. The Coalition Provisional Authority under Paul Bremer stopped local elections and sought through the agreement of November 15, 2003 to forestall open, one-person, one-vote elections in Iraq for years to come. The Americans sought reliable local elites as allies, and feared the unpredictability of open elections. The Shiite clerics were able to enlist the Iraqi masses in their quest to pressure the Occupation Powers into permitting open elections, both at the local and the national level. Local protests at Hilla, Nasiriyah, Amara, Kut and elsewhere were important in putting pressure on the CPA, and reflected discontents with lack of fuel and services as well as a feeling of being blocked politically by foreign appointees. But most dramatic of all were the massive demonstrations in Basra and Baghdad called in mid-January 2004 by Sistani.

The Shiite clerics were convinced of the compatibility of popular sovereignty with Islamic law at that point in Iraqi history, because they were sure that the Shiite masses in the South - constituting some 60 percent of the population - would vote for the Islamic parties and so ensure the triumph of sharia. Their vision of democracy therefore involved a conception of dual sovereignty, wherein clerical authority provided a bulwark against the possible irresponsibility of the enfranchised masses. Despite adoption of the language of "pluralism" (ta'addudiyyah) and expressing confidence that the rights of 
minorities would be protected, the clerics seemed remarkably unafraid of the consequences of a tyranny of the Shiite majority. They therefore seldom supported any practical checks or balances to protect minority rights. The language they favored was that of the general will of Jean-Jacques Rousseau, a democratic tradition notable for its lack of checks on majority power. Nevertheless, the clerics did speak clearly of minority rights and the need for pluralism, in a way that Khomeini never would have bothered to do. Something new is clearly being born in Iraq that does not in the least resemble the theocratic systems of Muhammad Baqir al-Sadr or Ayatollah Khomeini. It is being born of Iraqi history and thought, and as much in reaction against the US as in cooperation with it. Constitutionalism, open elections, and parliamentary bargaining are key to this new thinking among the Shiite clerics. In the phrase of sociologist Asef Bayat, their democratic thinking is a manifestation of "post-Islamism," and very possibly the beginning of the Islamic Enlightenment. 
Juan R.I. Cole is Professor of Modern Middle East and South Asian History at the University of Michigan. He has written extensively on modern Islamic movements in Egypt, the Persian Gulf, and South Asia. His current research focuses on Shiite Islam in Iraq and Iran and on the "jihadi" or "sacred-war" strain of Muslim radicalism, including al-Qaeda and the Taliban. His publications include Colonialism and Revolution in the Middle East: Social and Cultural Origins of Egypt's Urabi Movement (Princeton, 1993), and Modernity and the Millennium: The Genesis of the Baha'i Faith in the Nineteenth-Century Middle East (Columbia, 1998). His most recent book is Sacred Space and Holy War (IB Tauris, 2002), a collection of some of his papers on the history of the Shiite branch of Islam in modern Iraq, Iran, and the Gulf. He has given numerous media and press interviews on the "War on Terrorism" since 11 September 2001, as well as on the 2003 Iraq War. 
INTERNATIONAL INSTITUTE

FOR THE STUDY OF ISLAM

IN THE MODERN WORLD (ISIM)

Visiting address:

Rapenburg 59

2311 GJ Leiden

The Netherlands

Postal address:

P.O. Box 11089

2301 EB Leiden

The Netherlands

Telephone:

+31-(0)71-527 7905

Fax:

+31-(0)71-527 7906

E-mail:

info@isim.nl

Website:

www.isim.nl 